\title{
Pollution of Water, Soil and Vegetables: Challenges to Growing Cities of Bahir Dar and Kombolcha, Amhara Region, Ethiopia
}

\author{
Mekonnen Getahun ${ }^{1} \&$ Yihenew G. Selassie ${ }^{2}$ \\ ${ }^{1}$ Amhara Design and Supervision Works Enterprise, Bahir Dar, Ethiopia \\ ${ }^{2}$ College of Agriculture and Environmental Sciences, Bahir Dar University, Bahir Dar, Ethiopia \\ Correspondence: Yihenew G. Selassie, Department of Natural Resources Management, College of Agriculture \\ and Environmental Sciences, Bahir Dar University, Bahir Dar, Ethiopia. Tel: 251-918-765-823. E-mail: \\ yihenewgs@gmail.com
}

Received: June 14, 2013 Accepted: July 19, 2013 Online Published: August 15, 2013

doi:10.5539/jas.v5n9p22 URL: http://dx.doi.org/10.5539/jas.v5n9p22

\begin{abstract}
The study was conducted in Bahir Dar and Kombolcha growing industrial cities where urban agriculture is highly promoted. The research focused on determining the extent of contamination of soil, water and vegetables from wastewater used for irrigation and tried to suggest mitigation mechanisms against urban environmental pollution. To achieve the set objective, field works were carried out whereby soil, water and vegetables samples were collected and analyzed following standard laboratory procedures. Residents of the study areas were also interviewed to assess their attitude and observations on changes that might have occurred on the environment. Soil and water contamination levels were analyzed using World Health Organization and EU standards. Results of the study indicated that soil organic carbon, total nitrogen and available phosphorus levels were medium to high. At both experimental sites, the $\mathrm{Na}$ and $\mathrm{K}$ contents ranged from medium to high throughout the soil profile; however, the contents of $\mathrm{Ca}$ and $\mathrm{Mg}$ were high. The electrical conductivities (EC) of soils in the study ranged from 0.40 to $1.37 \mathrm{dS} \mathrm{m}^{-1}$ and were generally non-saline. The concentrations of heavy metals in soils samples for both Bahir dar \& Kombolcha sites were found to be within the permissible levels. Analytical results of waste water samples indicated high nitrate and phosphate levels which is expected to increase $\mathrm{N}$ and $\mathrm{P}$ supply to crops, but with poor management may also cause eutrophication downstream. Due to the release of waste waters from cities, boron concentrations at Borkena River (Kombolcha) and Lake Tana (Bahir Dar) were found to be higher than the permissible limits for irrigation. The wastewater drained to Lake Tana has turbidity values of 32.5 NTU and 17.22 NTU and the BOD was also found to be very high in many of the sampling sites. The results of vegetable analysis indicated that lettuce and Swiss chard accumulated higher levels of Fe, Mn and Zn at different sites of Bahir Dar, while cabbage accumulated more Fe at Kombolcha. Cabbage was generally the least accumulator of metals compared to lettuce and Swiss chard grown in Bahir Dar. Maximum permitted metal concentrations in leafy vegetables were higher for zinc, iron, manganese, nickel and lead. Generally, from the results of the experiment it was possible to conclude that proper environmental monitoring and reclamations should be done to avert adverse effects on the environment.
\end{abstract}

Keywords: contamination, soil, vegetables, wastewater, heavy metals

\section{Introduction}

Scarcity of surface and ground water for irrigation is an ever increasing problem around the world, owing to which, use of wastewater for agriculture has become a common reality in three-fourth of the cities of Asia, Africa and Latin America (Henning et al., 2001). Presence of pollutants like heavy metals in urban and industrial wastewaters results in contamination of water and soil. Household effluents, drainage water, business effluents, atmospheric deposition and traffic related emissions transported with storm water into the sewage system carry a number of pollutants and enrich the urban waste water with heavy metals (Pendias \& Pendias, 1992). An increase in metal concentration of soil is not just sufficient for potential risk assessment. It is mainly because the total metal content of soil will usually include fractions that are not immediately available to plants, microorganisms and soil fauna (Ihekeronye \& Ngoddy, 1985). However, gradual availability and uptake of heavy metals by plants is of major concern as it may enter to humans through food web (FAO, 2006). 
It is also apparent that prolonged exposure to heavy metals such as cadmium, copper, lead, nickel and zinc can cause deleterious health effects to human beings (Sauve et al., 2000). One dietary pathway that has a potential of contaminating our food could be through crops irrigated with contaminated waste water. It is apparent that the main sources of heavy metals to vegetable crops are their growth media (soil, air, nutrient solutions) from which they are taken up by the roots or foliage. Previous studies indicated that soils and vegetables grown in the $A k a k i$ River catchments, central Ethiopia contained elevated concentration of heavy metals (Fisseha Itana, 1998) and hence it is unsafe to use vegetables and forages grown under such environment for both human and animal consumption.

Vegetables grown in Bahir Dar around Lake Tana include Swiss chard (Beta vulgaris L. var. cicla), cabbage (Brassica oleracea L. var. capitata), and lettuce (Lactuca sativa L.). These vegetables are also often grown on the embankments along the Borkena River and its tributary streams in Kombolcha. These farms are irrigated with water from the lake and river waters that are heavily contaminated by waste disposal from different sides of the cities. With the increase in the urban population and industrialization, these water sources have now become further contaminated with various pollutants, among which are heavy metals. In addition, the products could be contaminated as farmers wash them with contaminated water before bringing them to market. The objective of the research was, therefore, to investigate the level of contaminations of soils, water and vegetables around Bahir Dar and Combolcha cities, Amhara Region, Ethiopia.

\section{Materials and Methods}

\subsection{The Study Areas}

The study was conducted around Bahir Dar and Kombolcha cities in Amhara Region in 2008. Bahir Dar is situated on the southern shore of Lake Tana. The city is located approximately $565 \mathrm{~km}$ north-west of Addis Ababa. Kombocha is found in the South Wollo Zone of the Amhara Region and located about $378 \mathrm{~km}$ north-east of Addis Ababa. The largest water body around Kombolcha is Borkena River flowing to the Awash River. Both cities are endowed with favorable conditions for developing urban agriculture through the application of irrigation using the available water sources. Hence, many residents in both cities are cultivating vegetables like cabbage, lettuce, tomato, potato, onion, pepper etc and perennial crops including Chat (Catha edulis) and coffee.

\subsection{Sample Collection and Analysis}

Soil, water and vegetable samples were collected from five selected sites around the shore of Lake Tana in Bahir Dar (Bata church, Christos Semra church, Saint George church, Felege-Hiwot hospital \& Tana hotel) out of which, one soil and four water samples were collected and sent to the laboratory for analyses. At Kombolcha experimental site, water samples were collected at three sites (Borkena, Leyoler \& Worka Rivers). However, two soil samples were collected from agricultural fields irrigated with waste water from streams and canals. A total of three soil samples were collected from the two sites at the depth of $0-25 \mathrm{~cm}$. After thorough mixing, one $\mathrm{kg}$ of representative sample from each field was collected. The soil samples were air dried, crushed with mortar and pestle and sieved through $2 \mathrm{~mm}$ mesh sieve. The soil samples were analyzed for texture, $\mathrm{pH}, \mathrm{EC}$, organic carbon, total nitrogen, phosphorus $(\mathrm{P})$, potassium $(\mathrm{K})$, Calcium $(\mathrm{Ca})$ and Magnesium $(\mathrm{Mg})$ following the procedures described by Okalebo (2002); whereby chromium $(\mathrm{Cr})$, cadmium $(\mathrm{Cd})$ and lead $(\mathrm{Pb})$ were measured using Atomic Absorption Spectrophotometer (AAS), analytical Jena Nov AA 300, after double distilled water has been used to zero the instrument.

Waste water samples were collected from Lake Tana and Borkena River in sterile plastic bags and carried to the laboratory. Lead ( $\mathrm{Pb}$ ), Cd and Cr contents, total suspended solids (TSS), total dissolved solids (TDS), biochemical oxygen demand (BOD), nitrate, phosphate, calcium, magnesium, potassium, sodium and chloride were determined in the laboratory following procedures described in APHA (1993). The samples were also analyzed for $\mathrm{pH}$, temperature, electrical conductivity (EC) and dissolved oxygen (DO) in the field using portable microprocessor probes and meters.

Vegetable samples of lettuce (Lactuca sativa), cabbage (Brassica oleracea); Swiss chard (Beta vulgaris L. var. cicla) from sampling sites of Bahir Dar and Kombolcha agricultural sites were freshly harvested and packed in labelled paper bags and transported to the laboratory for analysis. The vegetables were washed thoroughly with tap water for the removal of soil particles and further washed with distilled water. The vegetable samples were sun dried, crushed and ground to powder and used for elemental analysis as outlined in Singh and Sharma (2010). 


\section{Result and Discussion}

\subsection{Soils}

The topsoil pH had narrow range of 7.64 -7.78 (mildly alkaline) at Kombolcha and 5.7 (moderately acidic) at Bahir Dar. The soils at the two farms contained adequate plant nutrients which could give high vegetable yields. Organic carbon (OC) and nitrogen levels were medium to high ( 0.9 to $1.4 \%$ and 0.1 to $0.2 \%$, respectively) with a uniform distribution of carbon throughout the profile which could be attributed to the application of wastewater that is rich in organic matter (Table 1). Available phosphorus was high to extremely high ranging from 8 to $23 \mathrm{ppm}$ in the topsoil as well as the subsoil in both farms (Table 1). Selassie and Suwanarit (2007) reported that the critical P levels for maize production in Alfisols of western Amhara to be 11.6 and $14.6 \mathrm{ppm}$ for Olsen and Bray II methods, respectively.

The chemical analysis conducted on the irrigated command areas showed variations with respect to $\mathrm{Ca}^{2+}$ and $\mathrm{Mg}^{2+}$. Calcium is the dominant cation followed by $\mathrm{Mg}^{2+}$ (Table 1). Cation exchange capacity (CEC) ranged from 30.2 to $36.8 \mathrm{Cmol}_{\mathrm{c}} \mathrm{kg}^{-1}$. The CEC reflects the capacity of the soil to retain nutrients against leaching (Okalebo et al., 2002). As shown in the Table 1, the level of exchangeable cations such as sodium, potassium, calcium and magnesium concentrations in both experimental sites were high throughout the profiles (Metson, 1961). In both experimental sites, these nutrients were uniformly distributed in the soil profile and this may be due to the continuous additions of irrigation water and leaching effect.

Boulding (1994) classified EC of soils as non saline $\left(<2 \mathrm{dS} \mathrm{m}^{-1}\right)$, moderately saline $\left(2-8 \mathrm{dS} \mathrm{m}^{-1}\right)$, very saline (8-16 $\left.\mathrm{dS} \mathrm{m}{ }^{-1}\right)$; and extremely saline ( $\left.>16 \mathrm{dS} \mathrm{m}^{-1}\right)$. Based on classification of the soil on EC values, the experimental sites were non saline. As shown in Table 1, the concentration of heavy metals in soils samples was found within the acceptable range (Wild, 1988). The heavy metal concentrations in the cultivated soil samples from the Kombolcha agricultural site was in the order of $\mathrm{Fe}>\mathrm{Cu}>\mathrm{Mn}$. The concentrations of heavy metals showed spatial variations, which may be ascribed to the variation in heavy metal sources and the quantity of heavy metals in irrigation water and sewage sludge. This trend suggests that continuous application of sewage sludge and municipal wastewater will in the long run affect the soil physicochemical properties (Willett et al., 1984). It is also apparent that the amount of heavy metals mobilized in soil environment is a function of $\mathrm{pH}$, properties of metals, redox conditions, organic matter content, clay content, cation exchange capacity and other soil properties (Mukherjee, 1998; Kimberly \& William, 1999; Sauve et al., 2000). The results obtained from the experimental site showed that most of the heavy metals found in the soil considered are within the permissible level. However, heavy metals can accumulate in the soil through time and could be hazardous since crops are known to take up and accumulate heavy metals from contaminated soils in their edible portions (Wei et al., 2005).

Table 1. Physicochemical properties of soil samples from Kombolcha and Bahir Dar cities

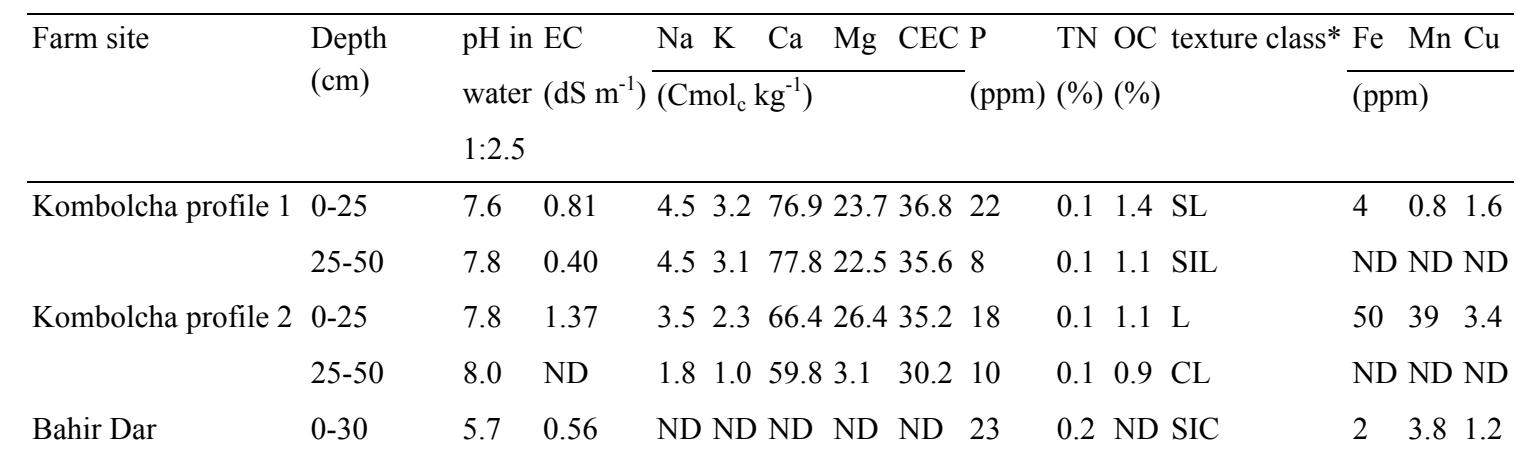

$* \mathrm{SL}=$ silty loam; $\mathrm{SIL}=$ silty; $\mathrm{L}=$ loam; $\mathrm{CL}=$ clay loam; $\mathrm{SIC}=$ silty clay; $\mathrm{ND}=$ not determined.

\subsection{Water}

The results of water analysis are presented in Table 2. In Cities like Bahir Dar, where people are closely living around Lake Tana, the change in color, odor and taste of the surface water is associated with organic and inorganic constituents of waste which are added to it. As observed during the field study, the surface of the lakeshore near Bahir Dar has a wide variety of colors and the odors along the southern gulf of the lake are bad, especially near Felege hiwot hospital. Near Saint George church, the lakeshore is used as a station for fishermen. Moreover, the site is mouth of the municipal wastewater from the center of the Bahir Dar city which adds tremendous 
contaminants to the lake. There are other many places which have drainage outlets from the city to Lake Tana. For instance, the Amhara Water Works Construction Enterprise disposes wastes (grease, oil and other products) to the lake. The drainage outlet, which comes from Engineering Campus of Bahir Dar University, contains dirt, polluted solid and liquid wastes. These are very dangerous sources of contamination to different vegetable crops growing in the border of Lake Tana, aquatic habitats and people washing their clothes and bodies using the lake water. In addition, washing of bodies and clothes using household detergents is another potential source of pollution.

The physicochemical analysis results of water from Borkena and its tributary rivers around Kombolcha city are presented in Table 2. The results show that metal composition of Leyole River water was complex and highly variable. The $\mathrm{pH}$ of the water ranged between 8.17 and 8.28 . These values, however, satisfy the $\mathrm{pH}$ requirement necessary for irrigation which is between 6.0 and 9.0 (Mengistu, 1998). Electrical conductivity of water ranged from 0.47 to $2.18 \mathrm{dS} \mathrm{m}^{-1}$. EC values of $<2$ indicate less salt concentration (FAO, 2006). Heavy metal analyses of water were done to check the suitability for agricultural use. As indicated in Table 2, the results of Fe concentration ranged from 0.1 to $0.8 \mathrm{mg} \mathrm{L}^{-1}$. The standard of Fe concentration for irrigation is $200 \mathrm{mg} \mathrm{L}^{-1}$ (USEPA, 1991; 1999). According to these limits, the water of Borkena River has no limitation for irrigation. The concentrations of $\mathrm{Cd}$ and $\mathrm{Pb}$ were also below detection limits. A guideline value for $\mathrm{Cd}$ in drinking water is $0.003 \mathrm{mg} \mathrm{L}^{-1}$ (WHO, 1993) and the irrigation standard recommended by USEPA for Cd concentration in water is $5 \mathrm{mg} \mathrm{L}^{-1}$. According to these standards, the river water may be used for irrigation without any harmful effect. The permissible limit of $\mathrm{Pb}$ by WHO and USEPA for drinking and irrigation purpose is 0.01 and $5 \mathrm{mg} \mathrm{L}^{-1}$, respectively. The results of the present study for $\mathrm{Pb}$ concentration revealed that Borkena River water may be suitable for both drinking and irrigation without any reservation. However, prolonged application of the wastewater under poorly managed irrigation system could lead to accumulation of these elements in the soil profile. The major industries from which effluents enter into Leyole River are Kombolcha tannery, textile factory, meat factory, metal and iron sheet factory. Additionally, wastes from garages and gas stations were discharged into this river. Most of the industries discharge their effluents that contained pollutants like heavy metals, organics and other toxicants such as minerals, oil residues, cleaning solvents, detergents, acids and alkalis, pathogenic organisms as well as a variety of salts of nitrate, sulfate, phosphate and chloride. Inhabitants of the area also described that as the result of bad odor from the tannery, many people contracted allergy (asthma) problems.

Nitrate at Leyole River and wastewater disposals from different localities were found to be between 58 and $84 \mathrm{mg}$ $\mathrm{L}^{-1}$. The amount of nitrate significantly exceeds the recommended limit of water for irrigation (WHO, 2006). The high nitrate levels in wastewater may increase $\mathrm{N}$ availability to crops, but with poor management, this may cause eutrophication downstream in cases where water flowed into dams or lakes. The highest chlorine ion $\left(\mathrm{Cl}^{-}\right)$ concentrations were recorded to be 109 and $101 \mathrm{mg} \mathrm{L}^{-1}$ for Leyole stream and wastewater disposed from Bahir Dar city through the canal passing between Saint George Church and Amhara Development Association (ADA) building, respectively which are above the critical values reported by Pescod and Arar (1988).

In all rivers around Komoblcha, the concentrations of $\mathrm{Cr}, \mathrm{Cd}, \mathrm{Ni}, \mathrm{Cu}, \mathrm{Zn}, \mathrm{Pb}, \mathrm{Mn}$ and $\mathrm{Fe}$ were below the threshold values that are considered to be toxic to crops according to WHO (2006). As far as macro elements are concerned, $\mathrm{Ca}$ was the dominant cation in both sites followed by $\mathrm{Mg}$ at Worka River and drainage out let of wastewater from the different kebeles at Bahir Dar (Table 2).

The phosphate concentration varied from 0.5 to $7.4 \mathrm{mg} \mathrm{L}^{-1}$ and 2.66 to $18.2 \mathrm{mg} \mathrm{L}^{-1}$ at Kombolcha and Bahir Dar, respectively, which is above the critical level of $0.1 \mathrm{mg} \mathrm{L}^{-1}$ (Hem, 1989). The source of phosphate concentration at experimental sites are domestic wastewater from cleaning agents, laboratories, brewery and from runoffs and agricultural activities in the surrounding areas (Table 2). Boron concentrations as $\mathrm{H}_{2} \mathrm{BO}_{3}$ at Borkena River, Lake Tana shores near ADA and Woramit sites were 1.04, 0.78 and $0.91 \mathrm{mg} \mathrm{L}^{-1}$, respectively that were found to be higher than the permissible limits for irrigation (Ayers \& Westcot, 1985). As shown in the Table 2, the high and low values of EC $\left(1.09\right.$ and $\left.0.022 \mathrm{dS} \mathrm{m}^{-1}\right)$ were recorded close to ADA building drainage inlet and at the drainage point near Woramit, respectively. The measured $\mathrm{pH}$ in all sites is meeting the FAO irrigation water quality standards (6.5-8.4) where as the total dissolved solids (TDS) in the same site are lying in slight to moderate limits (450-2000 $\left.\mathrm{mg} \mathrm{L}^{-1}\right)$.

Measurement of turbidity for pollution assessment has not been ideal because of the great variation with seasonal and daily fluctuations. The effect of turbidity is its interference with water treatment and is less acceptable to consumers from aesthetic point of view. Generally, turbidity analysis result indicated that the wastewater drained to Lake Tana has turbidity values of $32.5 \mathrm{NTU}$ and 17.22 NTU at ADA building and drainage outlet at Felegehiwot hospital, respectively. The BOD in the three inlets is high. This is because of the discharge of oxygen demanding waste from the different direction of the city in to the Lake Tana. The high turbidity at the ADA 
building is, for example, due to inlet of municipal wastewater drained from Keble (locality) 05, 06, 01 and 02 without any treatment.

Table 2. Physicochemical properties of water at different sites

\begin{tabular}{|c|c|c|c|c|c|c|c|c|}
\hline \multirow[b]{2}{*}{ Element } & \multicolumn{8}{|c|}{ Concentrations at streams feeding Kombolcha river $\left(\mathrm{mg} \mathrm{L}^{-1}\right)$ at Bahir Dar $\left(\mathrm{mg} \mathrm{L}^{-1}\right)$ Concentrations of drainages to Lake Tana } \\
\hline & Leyole & Borkena & Worka & Brewery & $\begin{array}{l}\text { Drainag } \\
\text { near } \\
\text { building }\end{array}$ & $\begin{array}{l}\text { De Drainage } \\
\text { ADAnear } \\
\quad \text { Woramit }\end{array}$ & $\begin{array}{l}\text { Drainage near } \\
\text { Felege-hiwot } \\
\text { hospital }\end{array}$ & $\begin{array}{l}\text { Michael } \\
\text { Church }\end{array}$ \\
\hline$\overline{\mathrm{K}^{+}}$ & 10.1 & 3.2 & 2 & 17 & 21.8 & 9.6 & ND & ND \\
\hline $\mathrm{Ca}^{2+}$ & 1 & 10 & 55 & 37 & 72 & 18 & ND & ND \\
\hline $\mathrm{Mg}^{2+}$ & 16 & 19 & 17 & 8 & 33 & 16 & ND & ND \\
\hline $\mathrm{Fe}^{2+}$ & 0.1 & 0.1 & $<0.1$ & 0.8 & 0.1 & 0.1 & ND & ND \\
\hline $\mathrm{Cl}^{-}$ & 109 & 28 & 11 & 17 & 101 & 40 & ND & ND \\
\hline $\mathrm{NO}_{3}{ }^{2-}$ & 58 & $<0.04$ & 10 & 4.4 & 84 & 1.33 & ND & ND \\
\hline $\mathrm{PO}_{4}{ }^{3-}$ & 12.4 & 2.73 & 0.5 & 74 & 18.2 & 2.66 & 18.2 & 5 \\
\hline $\mathrm{HBO}_{3}^{-}$ & 0.58 & 1.04 & 0.39 & 0.26 & 0.78 & 0.91 & ND & ND \\
\hline pH & 8.28 & 7.82 & 8.18 & 8.17 & 5.7 & 6.3 & 7.7 & 7.3 \\
\hline $\begin{array}{l}\mathrm{EC} \\
\left(\mathrm{dS} \mathrm{m}^{-1}\right)\end{array}$ & 0.84 & 2.18 & 1.09 & 0.47 & 1.09 & 0.02 & 0.22 & 0.20 \\
\hline $\begin{array}{l}\text { Turbidity } \\
\text { (NTU) }\end{array}$ & ND & ND & ND & ND & ND & ND & 17.22 & ND \\
\hline $\begin{array}{l}\mathrm{BOD} \\
\left(\mathrm{mg} \mathrm{L}^{-1}\right)\end{array}$ & ND & ND & ND & ND & 226.5 & 8.5 & 114 & 103.9 \\
\hline $\begin{array}{l}\operatorname{TDS} \\
\left(\mathrm{mg} \mathrm{L}^{-1}\right)\end{array}$ & ND & ND & ND & ND & 845 & 14.1 & 81.9 & 167.2 \\
\hline
\end{tabular}

$\mathrm{ND}=$ not determined.

\subsection{Vegetables}

Comparing the two contaminated sites, lettuce and Swiss chard accumulated $\mathrm{Fe}, \mathrm{Mn}$ and $\mathrm{Zn}$ at different sites of Bahir Dar, while cabbage accumulated more Fe at the Kombolcha (Table 3). Cabbage was generally the least accumulator of metals compared to the other two leafy vegetables grown in Bahir Dar. The metal concentrations in leafy vegetables were high for Fe, Mn, and Ni. Absorption capacity of heavy metals depends upon the nature of vegetables and some of them have a greater potential to accumulate higher concentrations of heavy metals than others. Lettuce is reported to accumulate more of heavy metals in humans through the edible portion (Intawongse $\&$ Dean, 2006).

The concentrations of $\mathrm{K}, \mathrm{Ca}$ and $\mathrm{Mg}$ were higher in cabbage plants grown by waste water where as the concentration was lower in those plants grown by non-polluted water. The concentrations of chromium (Cr), cadmium $(\mathrm{Cd})$, zinc $(\mathrm{Zn})$, cobalt $(\mathrm{Co})$ were below detection limits. Hence their current environmental effects are insignificant. 
Table 3. Metal and ion concentrations $\left(\mathrm{mg} \mathrm{kg}^{-1}\right)$ in some vegetables from Bahir Dar

\begin{tabular}{|c|c|c|c|c|c|c|c|}
\hline \multirow[b]{2}{*}{ Element } & \multicolumn{2}{|l|}{ Cabbage } & \multicolumn{2}{|l|}{ Lettuce } & \multicolumn{2}{|l|}{ Swiss Chard } & \multirow[b]{2}{*}{$\begin{array}{l}\text { Recommended. } \\
\text { maximum limit } \\
\text { for vegetables }\end{array}$} \\
\hline & $\begin{array}{l}\text { Non } \\
\text { polluted } \\
\text { water }\end{array}$ & $\begin{array}{l}\text { Polluted } \\
\text { water }\end{array}$ & $\begin{array}{l}\text { Non-polluted } \\
\text { water }\end{array}$ & $\begin{array}{l}\text { Polluted } \\
\text { water }\end{array}$ & $\begin{array}{l}\text { Non-polluted } \\
\text { water }\end{array}$ & $\begin{array}{l}\text { Polluted } \\
\text { water }\end{array}$ & \\
\hline $\mathrm{K}^{+}$ & 32990 & 42980 & 72990 & 50500 & 48740 & 54500 & NA \\
\hline $\mathrm{Ca}^{2+}$ & 5670 & 10840 & 9170 & 250 & 7420 & 8000 & NA \\
\hline $\mathrm{Mg}^{2+}$ & 2220 & 3940 & 2970 & 8150 & 6470 & 4400 & NA \\
\hline $\mathrm{Fe}^{2+}$ & 135 & 430 & 3590 & 935 & 1340 & 845 & 425.5 \\
\hline $\mathrm{Zn}^{2+}$ & 20 & 30 & 45 & ND & 35 & ND & 99.4 \\
\hline $\mathrm{Mn}^{2+}$ & 25 & 40 & 145 & 110 & 350 & 30 & 500.0 \\
\hline $\mathrm{Cu}^{2+}$ & 5 & 10 & 10 & 10 & 15 & 10 & 73.3 \\
\hline $\mathrm{Ni}^{2+}$ & ND & ND & ND & ND & 5 & 5 & 67.9 \\
\hline $\mathrm{Cl}^{-}$ & ND & ND & ND & 54950 & ND & 24150 & NA \\
\hline $\mathrm{PO}_{4}^{3-}$ & 13150 & 10800 & 8600 & 10250 & 9100 & 11050 & NA \\
\hline $\mathrm{HBO}_{3}{ }^{2-}$ & 0.45 & 0.85 & 1.43 & ND & 2.15 & $<0.13$ & NA \\
\hline
\end{tabular}

$\mathrm{ND}=$ not determined; $\mathrm{NA}=$ not available.

\section{Conclusions and Recommendations}

Farmers are using Borkena and its tributary water sources, carrying various liquid wastes from domestic and industrial activities in the city for irrigation purposes. However, the results of water and soil analysis indicated that, heavy metals including $\mathrm{Cr}, \mathrm{Cd}, \mathrm{Ni}, \mathrm{Cu}, \mathrm{Zn}, \mathrm{Pb}, \mathrm{Mn}$ and $\mathrm{Fe}$ were not a serious problems in the area. They are within the permissible limits of WHO and USEPA standards for both drinking and irrigation purposes. Moreover, their concentrations in vegetables are still low. As observed in the study, the impact of congested settlement and urbanization at Bahir dar city resulted in changes for the quality of the Lake Tana water. That is evident from the result of high concentration of contaminants at the localized sites including nitrates, oxygen demand wastes, inorganic constituents and microorganisms. Changes in colour, test and odour and turbidity are indicators for the presence of physical contaminants that impacted the water quality of Lake Tana. The major sources of these contaminants are wastes generated from households, commercials, hotels, bars, health sector institutions, garages, fuel stations and agricultural activities. To protect Lake Tana and Borkena River from pollutions, respective municipalities in Bahir Dar and Komobolcha cities should control municipal waste disposal systems directed to the lake and rivers. Moreover, raising awareness of the public on environmental health is critically important.

\section{Acknowledgments}

This paper is based on work conducted within the framework of the Swiss National Centre of Competence in Research (NCCR) North-South: Research Partnerships for Mitigating Syndromes of Global Change. The authors also acknowledge the Ministry of Science and Technology, the Amhara Regional Agricultural Research Institute and the Amhara Regional Bureau of Water Resources Development for the various supports provided for the research.

\section{References}

APHA. (1998). Standard methods for examination of water and wastewater (20th ed.). Washington DC: American Public Health Association.

Ayers, R. S., \& Westcot, D. W. (1985). Water Quality for Irrigation. FAO Irrigation \& Drainage paper 29.

Boulding, J. R. (1994). Description and sampling of Contaminated Soils. In F. L. Boca Raton (Ed.), AIfeild Guide (2nd ed.). Lewis Publishers.

FAO. (2006). Guidelines for soil description, Food and Agriculture Organization of the United Nation, Rome (4th ed.).

Fisseha, I. (1998). Metal concentrations of some vegetables grown with industrial liquid waste at Akaki”. SINET Ethiop Journal of Science, 21(1), 133-44. 
Henning, B. J., Snyman, H. G., \& Aveling, T. A. (2001). Plant-soil interactions of sludge-borne heavy metals and the effect on maize (Zea mays L.) seedling growth. Water SA, 27, 71-78.

Ihekeronye, A. I., \& Ngoddy, P. O. (1985). Integral Food Science and technology for the Tropics (p. 293). Oxford and London: Macmillian Education Ltd.

Intawongse, M., \& Dean, J. R. (2006). Uptake of heavy metals by vegetable plants grown on contaminated soil and their bioavailability in the human gastro-intestinal tract, Food additives and contaminants. http://dx.doi.org/10.1080/02652030500387554

Kimberly, M. F. H., \& William, H. (1999). Trace metals in Montreal urban soils and the leaves of Teraxacum officinale. Canadian Journal of Soil Science, 9, 385-387.

Mengistu, G. (1998). Effects of environmental factors on distribution of vegetation on the eastern slopes of South Welo highlands. MA Thesis, School of Graduate Studies, Addis Ababa University, Addis Ababa.

Metson, A. J. (1961). Methods of chemical analysis for soil survey samples. Soil Bureau Bulletin No. 12, New Zealand Department of Scientific and Industrial Research (pp. 168-175). Government Printer, Wellington, New Zealand.

Mukherjee, A. B. (1998). Nickel: a review of occurrence, uses, emissions, and concentration in the environment. Finland Environment Review, 6, 1-15.

Okalebo, J. R. (2002). Chemical analyses and procedures routinely practiced in Africa laboratories.

Pendias, A. K., \& Pendias, H. (992). Elements of Group VIII -Trace Elements in Soils and Plants. Boca Raton: CRC Press.

Pescod, M. B., \& Arar, A. (1988). Treatment and use of sewage effluent for irrigation. Proceedings of the FAO Regional seminar.

Sauve, S., Henderson, W., \& Allen, H. E. (2000). Solid-solution portioning of metals in contaminated soils: dependence on $\mathrm{pH}$, total metal burden, and organic matter. Environmental Science and Technology, 34, 1125- 1131. http://dx.doi.org/10.1021/es9907764

Singh, Anita and Sharma, Rajesh Kumar. (2010). Risk assessment of heavy metal toxicity through contaminated vegetables from waste water irrigated area of Varanasi, India.

USEPA. (1991, 1999). Secondary Contaminants level: Recommended maximum concentration of Heavey metals and inorganic constitute in water, Finalrule. US Environment Protection Agency, 56, 2564.

Wei, S., Zhou, Q., \& Xin, W. (2005). Identification of weed plants excluding the uptake of heavy metals.

WHO. (1993). Guidelines for drinking water quality (2nd ed., Vol. 1). Geneva: World Health Organization.

Wild, A. (1988). Russell's Soil Conditions and Plant Growth (11th ed.), Essex, UK: Longman Scientific \& Technical, Harlow.

Yihenew, G. S., \& Suwanarit, A. (2007). Evaluation of Soil-Test Methods for Indexing Availability of Phosphorus for Maize (Zea Mays L.) Grown on Alfisols of Northwestern Ethiopia. Ethiopian Journal of Natural Resources, 9(1), 1-18.

\section{Copyrights}

Copyright for this article is retained by the author(s), with first publication rights granted to the journal.

This is an open-access article distributed under the terms and conditions of the Creative Commons Attribution license (http://creativecommons.org/licenses/by/3.0/). 